\title{
Stormwater and Fire as Sources of Black Carbon Nanoparticles to Lake Tahoe
}

\author{
Marion M. Bisiaux,, ${ }^{* \dagger}$ Ross Edwards, ${ }^{\neq, \dagger}$ Alan C. Heyvaert, ${ }^{\dagger}$ James M. Thomas, ${ }^{\dagger}$ Brian Fitzgerald, ${ }^{\dagger}$ \\ Richard B. Susfalk, ${ }^{\dagger}$ S. Geoffrey Schladow, ${ }^{\S}$ and Melissa Thaw ${ }^{\dagger}$ \\ ${ }^{\dagger}$ Division of Hydrologic Sciences, Desert Research Institute, Reno, Nevada 89512, United States \\ ${ }^{\ddagger}$ Department of Imaging \& Applied Physics, Curtin University of Technology Bentley, Perth, Western Australia 6102

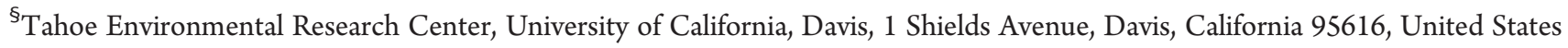

Supporting Information

\begin{abstract}
Emitted to the atmosphere through fire and fossil fuel combustion, refractory black carbon nanoparticles (rBC) impact human health, climate, and the carbon cycle. Eventually these particles enter aquatic environments, where they may affect the fate of other pollutants. While ubiquitous, the particles are still poorly characterized in freshwater systems. Here we present the results of a study determining $\mathrm{rBC}$ in waters of the Lake Tahoe watershed in the western United States from 2007 to 2009. The study period spanned a large fire within the Tahoe basin, seasonal snowmelt, and a number of storm events, which resulted in pulses of urban runoff into the lake with $\mathrm{rBC}$ concentrations up to 4 orders of magnitude higher than midlake concentrations. The results show that $\mathrm{rBC}$ pulses from both the fire and urban runoff were rapidly attenuated suggesting unexpected aggregation or degradation of the particles. We find that those processes prevent $\mathrm{rBC}$ concentrations from building up in the clear and oligotrophic Lake Tahoe. This rapid removal of $\mathrm{rBC}$ soon after entry into the lake has implications for the transport of $\mathrm{rBC}$ in the global aquatic environment and the flux of $\mathrm{rBC}$ from continents to the global ocean.

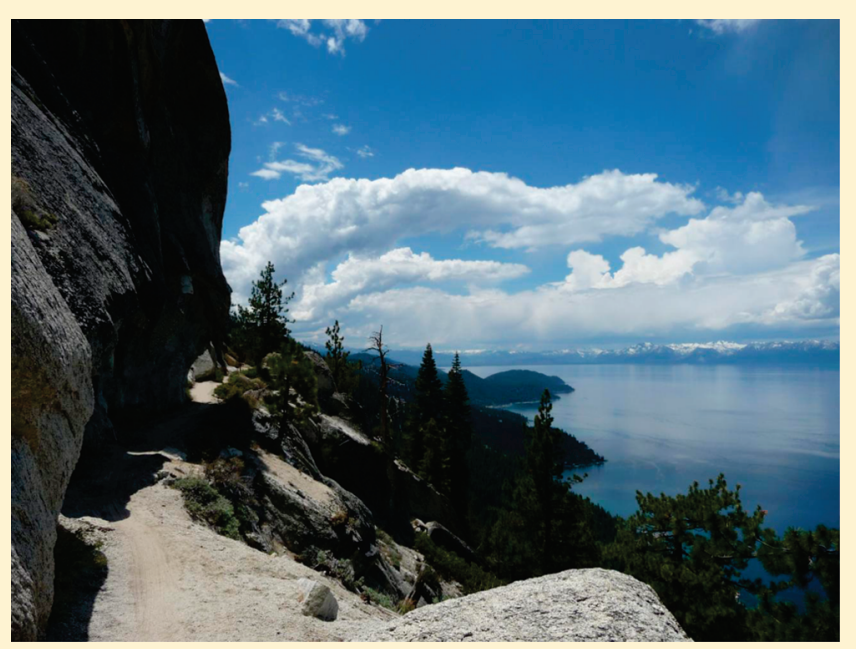

\section{INTRODUCTION}

Black carbon is a component of the freshwater environment that has been poorly characterized. ${ }^{1-3}$ Produced from the incomplete combustion of vegetation (fires), fossil fuels, and petrogenic processes (mineral, graphite), black carbon comprises a spectrum of related materials ranging from charred vegetation to refractory graphitic nanoparticles. ${ }^{4}$ These materials are present throughout the Earth system, impacting climate, ${ }^{5-7}$ the carbon cycle, ${ }^{1,8-10}$ and human health. ${ }^{11,12}$ Notably, several studies have shown that black carbon is a significant component (up to $20 \%$ ) of sedimentary organic carbon in the remote ocean ${ }^{13}$ and could represent a significant carbon sink. ${ }^{1}$ While particulate black carbon (diameter $>0.45 \mu \mathrm{m}$ ) have been determined in soils ${ }^{14,15}$ and sediments, ${ }^{1,15}$ the low concentrations of black carbon suspended in fresh water bodies and in the oceans have proven more difficult to analyze. ${ }^{16-18}$ The abundance and sources of black carbon in freshwater and the fraction exported to the ocean are thus almost unknown as well as its effect on aquatic chemistry.

In this paper, we focus our interest only on refractory black carbon nanoparticles (rBC) of diameters comprised between 60 and $400 \mathrm{~nm}$. Those particles can be produced from the fragmentation of charcoal or from the gas-phase condensation and subsequent carbonization of pyrolysis emissions (ref 19 and references therein). In this last case, $\mathrm{rBC}$ typically consists of fractal aggregate chains of spherules with diameters of $\sim 30$ to $40 \mathrm{~nm}^{20,21}$ capable of long-range transport in the atmosphere and thus available as tracers for smoke emissions. ${ }^{22}$ In both cases, the particles are very refractory (i.e., vaporizing only at very high temperature), have very large surface areas, and are potent adsorbers of polycyclic aromatic hydrocarbons (PAHs) and persistent organic pollutants (POPs). ${ }^{23-27}$ Initially hydrophobic, partial surface oxidation or coating of the particles with organic species ${ }^{19}$ allow it to disperse in water forming hydrosols small enough to be ingested by biota.

The objective of this study was to gain a basic knowledge of $\mathrm{rBC}$ hydrosols in freshwater by investigating the concentrations,

Received: June 25, 2010

Accepted: February 3, 2011

Revised: February 2, 2011 


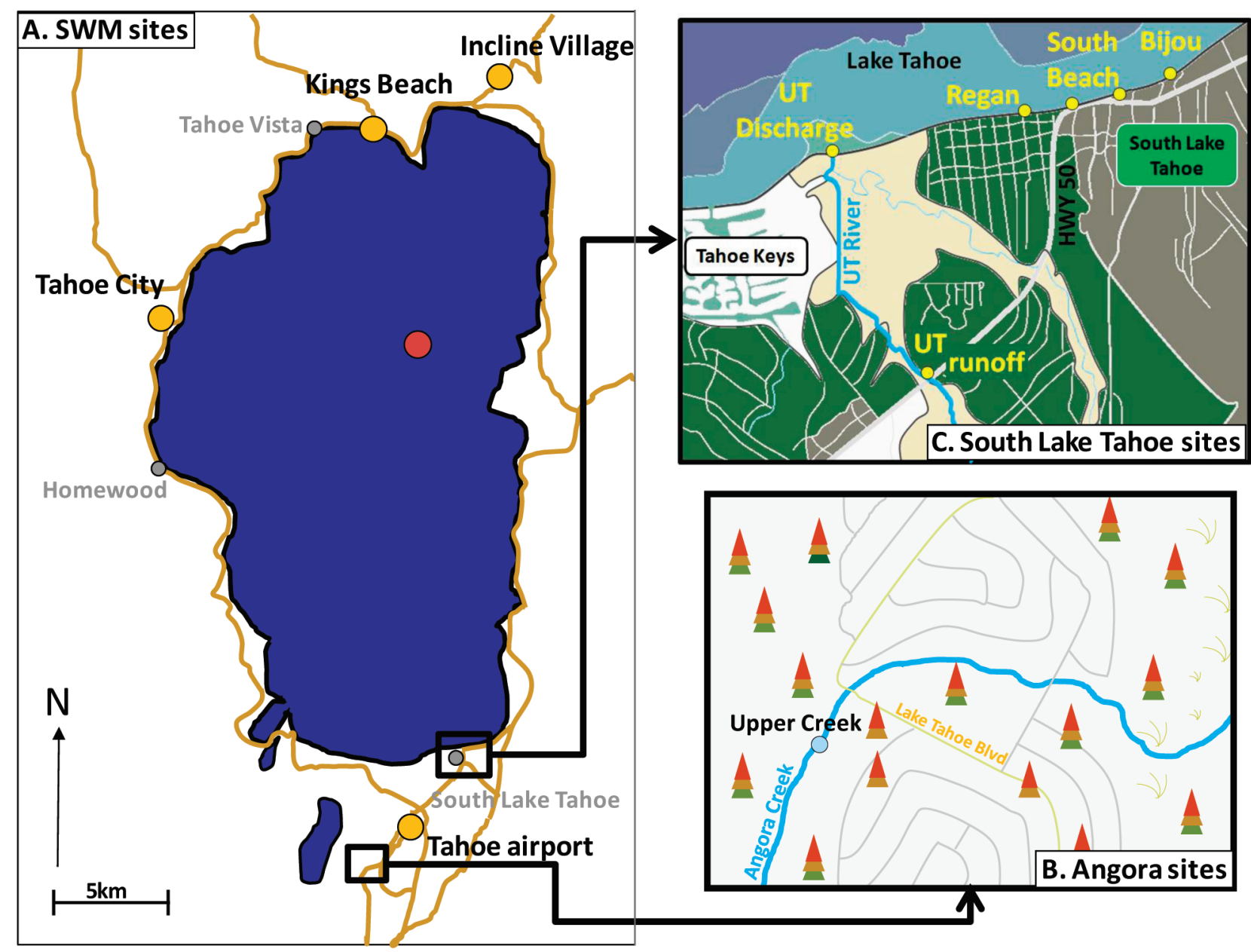

Figure 1. Map of sample locations around Lake Tahoe. A: In orange are the SWM sites and in red the MLTP station. Part B shows a drawing of the Angora neighborhood with the two sampling sites. Part C is a map of sampling sites at South Lake Tahoe, for stream sampling sites (Upper Truckee River (UT) sites) and near shore sampling sites (Regan, South Beach, Bijou).

variability, and likely sources of $\mathrm{rBC}$ in an oligotrophic lake. The study was performed in Lake Tahoe and its watershed (NV-CA, United States), famous for its water clarity and relatively pristine setting in the Sierra Nevada Mountains. However, small urban centers and roads encircle the lake, leading to inputs of urban runoff. Concentrations of rBC in urban runoff, streams, the lake's near-shore zone, and midlake water column were examined between January 2007 and September 2009. This time period included a major fire (Angora fire), which occurred from June 26th to July second, near the southwestern end of the lake. The fire allowed the examination of an increase of $\mathrm{rBC}$ aerosols on the lake and its mobilization from the fire site to a nearby stream.

\section{MATERIALS AND METHODS}

Water Sample Collection. Midlake. Water column samples were collected by the University of California-Davis as part of their mid-Lake Tahoe profile (MLTP) station time series. Each profile consisted of approximately 12 samples taken at lake depths ranging from 0 to $450 \mathrm{~m}$, with a sample collection occurring almost every month from January 2007 through January 2009.

Urban Runoff. Automated samplers collected untreated water discharging into Lake Tahoe from urban areas as part of a previously established regional stormwater monitoring program
(Desert Research Institute and the University of California-Davis Tahoe Environmental Research Center ${ }^{28}$ ). Four storm events were sampled from October 2007 to January 2009 at stations located in Tahoe City, Kings Beach, Incline Village, and South of Tahoe Airport. To study rBC in the fire affected Angora watershed, samples were collected from the upper Angora Creek (Figure 1A) during July 2007 and January 2009. This watershed suffered a large forest fire in summer 2007 from June 26th to July second which destroyed more than 1200 ha of forest and over 240 homes.

Free Runoff. Water from free runoff (not from culverts) was also sampled (grab samples) from random locations at five sites in South Lake Tahoe during the spring of 2009 on four different days corresponding to four different weather conditions. Two of these sites were located $25 \mathrm{~m}$ from Highway 50 between the road and the beach (South Beach sites). The Bijou and Regan sites were also on the south shore but farther away $(\sim 350 \mathrm{~m})$ from Highway 50 . The last site collected stormwater runoff released into the Upper Truckee River from nearby Highway 50 and $3 \mathrm{~km}$ upstream from where the stream discharges into Lake Tahoe (Figure 1C).

Near Shore Zone. Spatial and temporal variability of the rBC concentrations in the Near Shore Zone (NSZ) of South Lake Tahoe was investigated. NSZ was defined as the water band starting at $1 \mathrm{~m}$ from the beach-water interface and extending into the lake up to $100 \mathrm{~m}$ or until the water depth reached $7.5 \mathrm{~m}$. Lake 


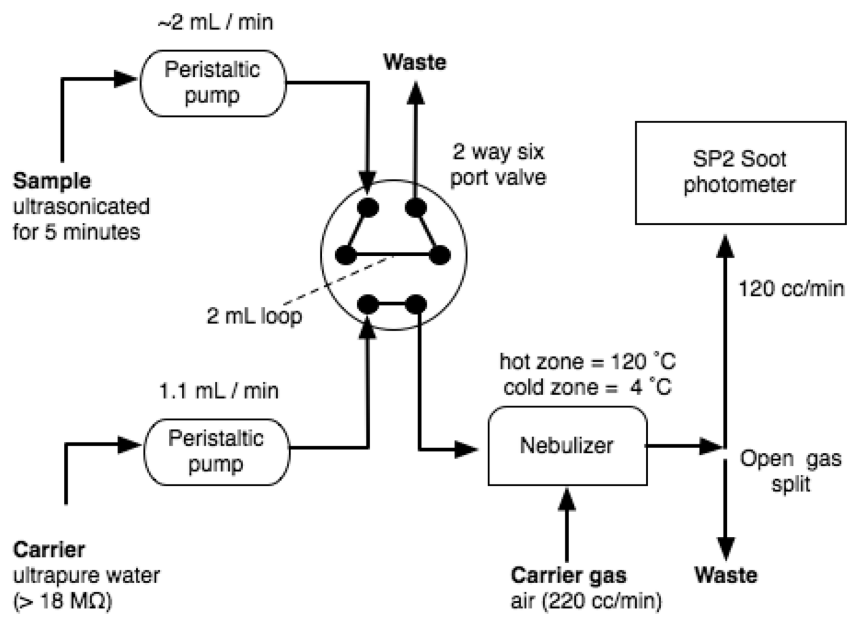

Figure 2. Schematic of the coupled SP2-FIA analytical system.

water was sampled at four sites along the South Lake Tahoe shore (Figure 1C) with a centrifuge tube hand-dipped into lake water from a canoe. NSZ sample sites from west to east are as follows: Upper Truckee discharge, Regan, South Beach, and Bijou, corresponding to the "off shore" locations of onshore stormwater monitoring sites (Figure 1C). At the NSZ sites, samples were collected during three storm events and one clear day of spring 2009 and at distances of about 1, 10, 50, and $100 \mathrm{~m}$ from the shore.

Flow Injection-SP2 Black Carbon Analysis. Concentrations of $\mathrm{rBC}$ were determined using a single particle intracavity laser induced incandescence photometer (SP2, Droplet Measurement Technologies, Boulder, Colorado) coupled to a Flow Injection (FIA) system with ultrasonic nebulization/desolvation (CETAC UT5000), Figure 2. Analyses of rBC aerosols using the SP2 have been described in detail in several papers ${ }^{29-31}$ including interinstrumental comparisons with other black carbon analytical methods. $^{32}$ The SP2 determines rBC from the wavelength resolved incandescent light emitted by individual $\mathrm{rBC}$ particles heated to their boiling point $(3700$ to $4300 \mathrm{~K})$ inside an intracavity ND-YAG laser $(1064 \mathrm{~nm})$. As a result of the unique boiling range of $\mathrm{rBC}$ (higher than pure silicon or nickel), the method is free of positive interferences from organic substances such as humic acids or PAHs, either as aerosol particles or coatings in $\mathrm{rBC}^{33,34}$ Furthermore, the method is insensitive to $\mathrm{rBC}$ particle morphology ${ }^{35}$ but restricted to a particle size range of $\sim 60$ to $400 \mathrm{~nm}$ depending on particle density. This size range is smaller than typical charcoal fragments or mineral graphite particles. ${ }^{36}$ In the FIA adaption of the method, $2 \mathrm{~mL}$ samples are injected into an ultrapure water carrier, nebulized, and desolvated before passing through the SP2. Concentrations of $\mathrm{rBC}$ are determined using a calibration of the incandescent light intensity to individual $\mathrm{rBC}$ particle mass combined with an external calibration of the FIA/nebulizer system using commercial pigments of known rBC concentration (Aquablack 162, Tokai Carbon, Tokyo) see the SI and Figure S1. External calibrations were performed daily for concentrations ranging from 0.03 to $80 \mu \mathrm{g} / \mathrm{L}$ with 10 standards. Procedural blanks were investigated using filtered lake and river water $(<20 \mathrm{~nm}$, Anopore filter $)$ and were below the detection limit $(\sim 0.01 \mu \mathrm{g} / \mathrm{L}, 3 \sigma)$. Instrumental blanks were prepared from ultrapure water (>18 M $\Omega$ ) and were also below the detection limit. Replicate samples, a quality control standard, and an instrumental blank were run

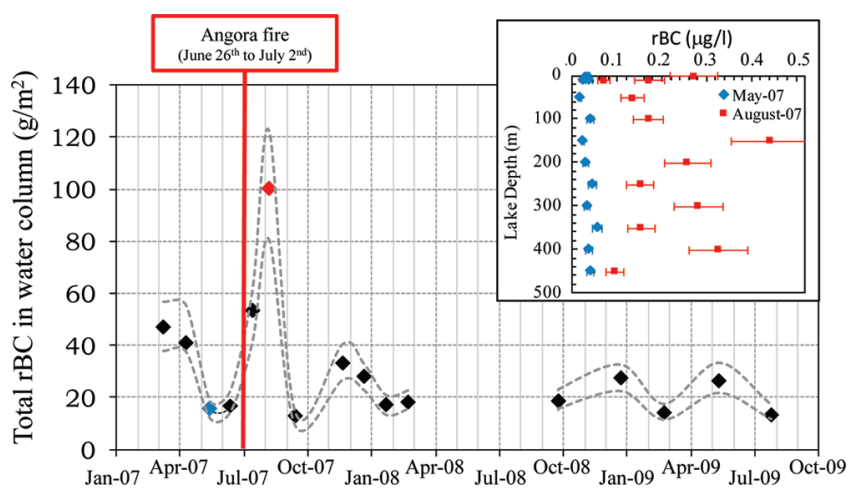

Figure 3. Total $\mathrm{rBC}$ in Lake Tahoe mid-lake site water column (in $\mathrm{g} / \mathrm{m}^{2}$ ) from February 2007 to January 2009. The red line shows the timing of the Angora fire, which damaged $12.5 \mathrm{~km}^{2}$ of land in the Southern Lake Tahoe area. The gray dashed lines display the error envelope for total $\mathrm{rBC}$ data points. On the insert in the top right hand corner is shown two rBC midlake profiles for the specific months of May and August 2007 (in $\mu \mathrm{g} / \mathrm{L}$ ), illustrating the disturbance induced by the fire on $\mathrm{rBC}$ concentrations.

every 10 samples with a standard deviation of less than $10 \%$ for concentrations above $0.1 \mu \mathrm{g} / \mathrm{L}$ and $\sim 20 \%$ for lower concentrations. Samples with concentrations exceeding $30 \mu \mathrm{g} / \mathrm{L}$ were diluted with ultrapure water to concentrations lower than $20 \mu \mathrm{g} / \mathrm{L}$.

\section{RESULTS AND DISCUSSION}

rBC Response to the Angora Wildfire. Midlake Concentrations. $\mathrm{rBC}$ concentrations in midlake samples displayed high variability with depth and time ranging from 0.02 to $0.45 \mu \mathrm{g} / \mathrm{L}$ with a geometric mean of $0.05 \mu \mathrm{g} / \mathrm{L}$. For a lake volume of about $180 \mathrm{~km}^{3}$, this represents a total $\mathrm{rBC}$ mass of $\sim 9$ tons or 0.01 to $0.02 \%$ of the Dissolved Organic Carbon (DOC) pool, assuming fairly low DOC concentrations ranging from 300 to $400 \mu \mathrm{g} / \mathrm{L}$ (Stuart Goldberg, UCSD, personal communication). Orders of magnitude higher black carbon concentrations have been reported in seawater $\left(\sim 800\right.$ to $3700 \mu \mathrm{g} / \mathrm{L}$ in Gulf of Mexico, ${ }^{16} \sim 90$ to $280 \mu \mathrm{g} / \mathrm{L}$ in the Chesapeake Bay $\left.{ }^{37}\right)$ and in river water $(\sim 100$ to $400 \mu \mathrm{g} / \mathrm{L}$ in the Delaware river $^{37}$ ). However, these studies were based on the indirect measurement of black carbon decomposition products (hydrogen deficient molecules), not measured with the SP2 method (this paper). In contrast, black carbon measurements in the Gulf of Maine established concentrations in particulate organic carbon (large nondissolved black carbon particles of diameter $>700 \mathrm{~nm}$ ) ranging from only 0.1 to $16 \mu \mathrm{g} / \mathrm{L},{ }^{38}$ overlapping the concentrations found in Lake Tahoe with the SP2 method, albeit a larger particle size range. In order to compare these various studies, the relationship between black carbon decomposition products, particulate black carbon $(>700$ $\mathrm{nm}$ ) and $\mathrm{rBC}$ needs further investigation.

Seasonal Variability. The seasonal variability of the total water column $\mathrm{rBC}$ is shown in Figure 3 as well as an insert illustrating two rBC profiles (concentration/depth) for May and August 2007. The total water column rBC time-series displays minima in May-June 2007, September 2007, and January-February 2008 and $2009\left(<20 \mathrm{~g} / \mathrm{m}^{2}\right)$ and a maximum in July-August 2007 (55 and $100 \mathrm{~g} / \mathrm{m}^{2}$, respectively). The relatively high values of March and April $2007\left(\sim 45 \mathrm{~g} / \mathrm{m}^{2}\right)$ correspond to the onset of snowmelt at lower urbanized elevations. In contrast, the low rBC values during the months of May and June are synchronous with 
Table 1. rBC Concentrations and Discharge Data at the Storm Water Monitoring Stations for Four Storm Events

\begin{tabular}{|c|c|c|c|c|}
\hline & \multirow{2}{*}{$\begin{array}{l}\text { Winter } 08 \\
\text { Jan-2008 }\end{array}$} & \multicolumn{3}{|c|}{ Winter 2009} \\
\hline & & Oct-2008 & Nov-2008 & Jan-2009 \\
\hline \multicolumn{5}{|c|}{ rBC Concentrations $(\mu \mathrm{g} / \mathrm{L})$ Per Event Per Site } \\
\hline Tahoe City & 50.7 & 82.6 & 11.6 & na \\
\hline Kings Beach & 126.3 & 157.0 & 56.9 & 96.4 \\
\hline Incline Village & 174.9 & 334.8 & 99.2 & 138.6 \\
\hline Tahoe Airport & 351.3 & 127.9 & 156.0 & 281.2 \\
\hline Angora Creek & na & na & 0.1 & 0.5 \\
\hline \multicolumn{5}{|c|}{ Runoff Volume Per Event $\left(\mathrm{m}^{3}\right)$ Per Site } \\
\hline Tahoe City & 96 & 26 & 98 & 179 \\
\hline Kings Beach & 25 & 1 & 12 & 26 \\
\hline Incline Village & 3 & 1 & 4 & 6 \\
\hline Tahoe Airport & 97 & 21 & 69 & 57 \\
\hline \multicolumn{5}{|c|}{ rBC Input to Lake Per Event (kg) Per Site } \\
\hline Tahoe City & 0.14 & 0.06 & 0.03 & na \\
\hline Kings Beach & 0.09 & $>0.01$ & 0.02 & 0.07 \\
\hline Incline Village & 0.02 & 0.01 & 0.01 & 0.02 \\
\hline Tahoe Airport & 0.96 & 0.07 & 0.30 & 0.46 \\
\hline \multicolumn{5}{|c|}{ Total Runoff Per Winter (m) Per Site } \\
\hline Tahoe City & 87,382 & & 114,212 & \\
\hline Kings Beach & $2226^{a}$ & & 3818 & \\
\hline Incline Village & 3721 & & 2744 & \\
\hline Tahoe Airport & 11,582 & & $18265^{a}$ & \\
\hline Angora Creek & $2,293,664$ & & $3,426,338$ & \\
\hline
\end{tabular}

rBC Inputs to the Lake Per Winter (kg) Per Site

$\begin{array}{lll}\text { Tahoe City } & 4.4 & 5.4 \\ \text { Kings Beach }^{a} & 0.3 & 0.4 \\ \text { Incline Village } & 0.7 & 0.5 \\ \text { Tahoe Airport } & 4.1 & 3.4 \\ \text { Angora Creek } & \text { na } & 1.6\end{array}$

${ }^{a}$ A gap in data for total discharge estimations, thus, those numbers have to be used with caution and just as indications.

broad basin runoff from higher elevation nonurbanized snowmelt, which brings a large volume of water to the lake. ${ }^{39}$ The twoto-4-fold increase in rBC during July and August 2007 corresponds to the Angora fire, which occurred from June 26th to July second 2007. After the fire, there was no rain over the watershed for the remainder of July and August. Therefore we assume that fire inputs of $\mathrm{rBC}$ should have contributed to lake concentration through dry deposition onto the lake surface. After this transient maximum, $\mathrm{rBC}$ concentrations in the lake decreased and stayed low until the end of sampling in August 2009.

Angora Site. Observations from the Angora Creek, within and immediately downstream of the fire area (Figure 1B), also suggest low $\mathrm{rBC}$ inputs from streams into the lake. Overall, from July 2007 to January 2009, rBC concentrations at the upper Angora Creek ranged from 0.3 to $1 \mu \mathrm{g} / \mathrm{L}$. Three days after the fire

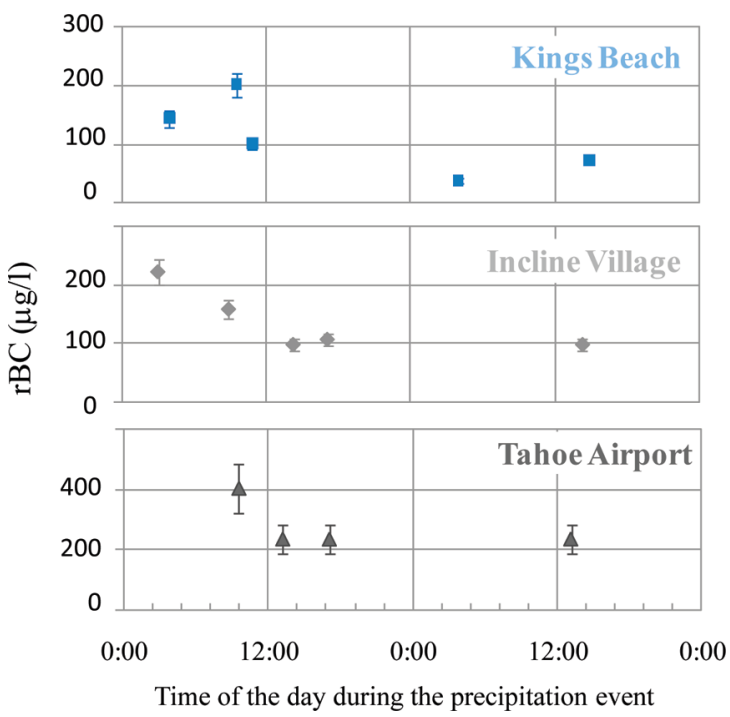

Figure 4. Distribution of $\mathrm{rBC}$ concentrations in $\mu \mathrm{g} / \mathrm{L}$ during the single storm event of January 22, 2009 at three SWM sites (Kings Beach, Incline Village, and Tahoe Airport). A first "flushing" effect is visible, followed by a tail of steady concentrations.

(July fifth) and a year and a half later (January 23rd 2009) the upper Angora Creek site also exhibited low rBC concentrations with levels similar to the ones observed in the middle of the lake $(0.3 \mu \mathrm{g} / \mathrm{L})$. Assuming an average concentration of $0.5 \mu \mathrm{g} / \mathrm{L}$, the rBC input to Lake Tahoe from Angora Creek was about $\sim 1.6 \mathrm{~kg}$ for the winter 2009 (Table 1). Since the Creek represents about $1 \%$ of the watershed runoff inputs to Lake Tahoe, the stream was probably a negligible source of $\mathrm{rBC}$ to the lake during and after the fire, confirming the hypothesis that the increase in $\mathrm{rBC}$ lake concentrations synchronous to the fire was driven by atmospheric dry deposition processes. These results also imply that $\mathrm{rBC}$ deposited to soil is relatively immobile.

rBC Input to Lake Tahoe from Urban Stormwater Runoff. Concentrations of $\mathrm{rBC}$ in urban stormwater runoff samples were systematically higher than in the midlake samples by a factor of 100 to 1000, supporting the existence of additional sources of $\mathrm{rBC}$ not related to forest fires. Runoff $\mathrm{rBC}$ concentrations were rarely less than $5 \mu \mathrm{g} / \mathrm{L}$ and were often in the 30 to $100 \mu \mathrm{g} / \mathrm{L}$ range. $\mathrm{rBC}$ concentrations in highway stormwater runoff samples were typically between 100 to $400 \mu \mathrm{g} / \mathrm{L}$ and as high as $600 \mu \mathrm{g} / \mathrm{L}$.

Storm Water Monitoring. Stormwater monitoring (SWM) samples provide an overview of $\mathrm{rBC}$ concentrations in runoff in relation to urbanization type. Table 1 displays the $\mathrm{rBC}$ concentrations in composite samples representing the average concentration for an entire storm event. South Tahoe Airport (site exhibiting the larger commercial/industrial activities) and Incline Village (highest residential coverage) showing elevated $\mathrm{rBC}$ concentrations (from 100 to $350 \mu \mathrm{g} / \mathrm{L}$ ). Lower $\mathrm{rBC}$ concentrations were observed for stormwater draining less populated and commercialized areas (from 10 to $150 \mu \mathrm{g} / \mathrm{L}$ at Kings Beach and Tahoe City). Those concentrations at each site were extrapolated to the total runoff volume of the events to estimate $\mathrm{rBC}$ inputs to the lake (Table 1). At South Tahoe Airport (relatively high concentrations and high volumes), the runoff could have brought between 0.1 to $1 \mathrm{~kg}$ of $\mathrm{rBC}$ to the lake every event. On the contrary, Incline Village runoff seems to be a small source of $\mathrm{rBC}$ to Lake Tahoe ( $\sim 10 \mathrm{~g} /$ event $)$ despite high concentrations. Over the whole winter 2009, each site may have discharged between 


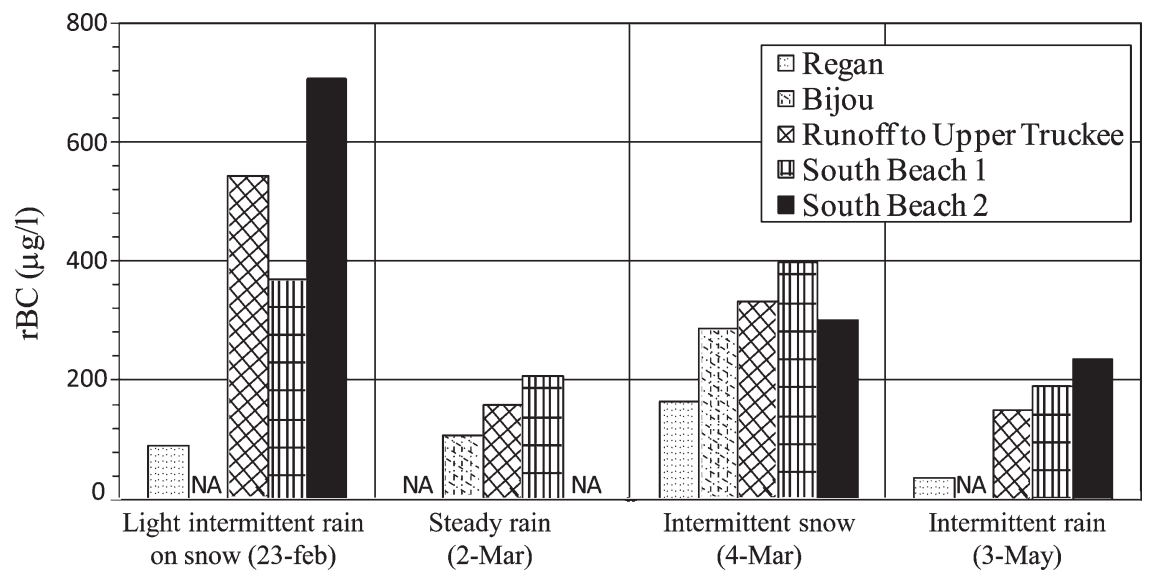

Figure 5. $\mathrm{rBC}$ concentrations in $\mu \mathrm{g} / \mathrm{L}$ in runoff at the five South Lake Tahoe sites and the days (year 2009) and weather conditions during sampling.

$\sim 0.4 \mathrm{~kg}$ (Kings Beach) to $\sim 5.4 \mathrm{~kg}$ (Tahoe City) of rBC, Table 1 . This is much higher than for Angora Creek $(\sim 1 \mathrm{~kg} /$ year $)$, even though the discharge of the creek is 20 to 1000 times larger than at the runoff sites.

Distribution of $\mathrm{rBC}$ concentrations for samples collected at different times of the precipitation event of January 22th at three locations (Kings Beach, Incline Village and South Tahoe Airport) shows higher concentrations at the beginning of the event than at the end, demonstrating an initial flushing effect (Figure 4).

Free Runoff. In samples collected from free runoff (surface water runoff, not from culverts), $\mathrm{rBC}$ concentrations were in the same order of magnitude as in SWM samples (culvert runoff). Replicate samples at one site and during one storm event had very similar concentrations (variability $<10 \%$ ); however, $\mathrm{rBC}$ concentrations varied from one site to another and from one day to another, sometimes by several orders of magnitude and depending on the total runoff volume (Figure 5). On February 23rd, we measured an averaged $\mathrm{rBC}$ concentration of $430 \mu \mathrm{g} / \mathrm{L}$ during a $24 \mathrm{~h}$ period of intermittent rain which transported a total water volume of $340 \mathrm{~m}^{3}$ through the Bijou SWM site (chosen as reference for runoff volume). On March second, runoff sampled during steady rain conditions and higher runoff volume $\left(3060 \mathrm{~m}^{3}\right)$ had lower concentrations than during the first storm (average rBC concentration: $150 \mu \mathrm{g} / \mathrm{L}$ ). On March fourth, occasional snow showers produced less water for runoff than the March second event $\left(400 \mathrm{~m}^{3}\right)$ and $\mathrm{rBC}$ was comparatively more concentrated (average $\mathrm{rBC}$ concentration: $300 \mu \mathrm{g} / \mathrm{L}$ ). Finally, on May third, sampling took place after a two day period of scattered rain showers ( total runoff volume $400 \mathrm{~m}^{3}$ ), but in this case $\mathrm{rBC}$ concentrations were also low $(150 \mu \mathrm{g} / \mathrm{L})$. Overall, concentrations during the major rain event of March second were lower than during the light precipitation events of February 23th and March fourth, suggesting dilution processes. However, low $\mathrm{rBC}$ concentrations also observed during the low volume runoff on May third may indicate that urban $\mathrm{rBC}$ sources were smaller during the spring than in the winter (heavier road use, wood burning). Higher $\mathrm{rBC}$ concentrations and loads (due to higher flow rates) were also consistently found in sites close to Highway 50 (South Beach and Upper Truckee River), and the lower concentrations were observed for the commercial and residential sites (Bijou and Regan). Thus, the $\mathrm{rBC}$ concentrations appear directly related to traffic volume and may be used as an indicator for traffic pollution, as previously suggested by other studies. ${ }^{40}$

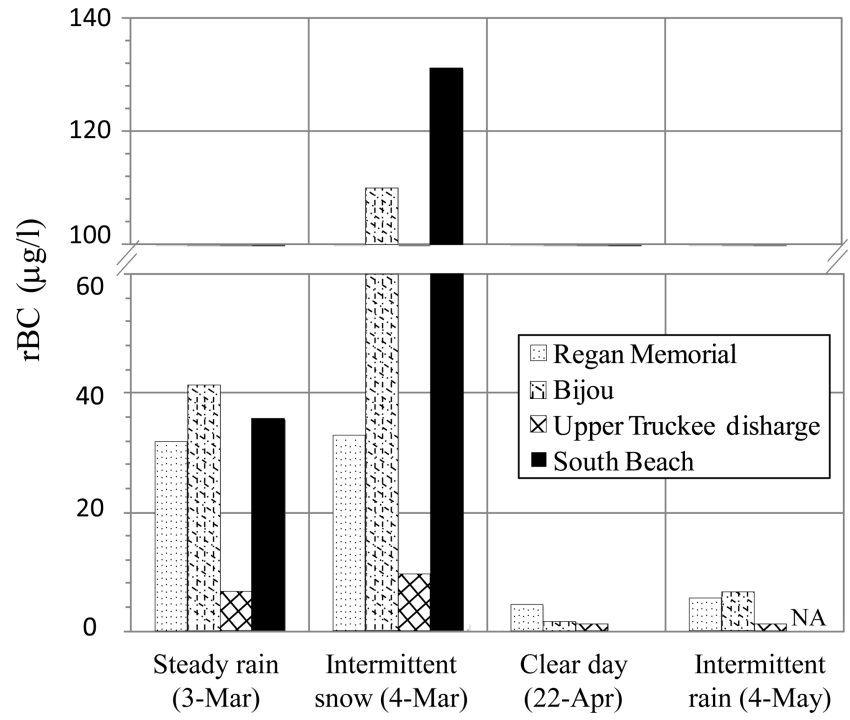

Figure 6. $\mathrm{rBC}$ concentration for near shore samples (lake samples) at the four South Lake Tahoe sites for the three storm events and one clear day monitored in the spring 2009, averaged for distances $1 \mathrm{~m}$ and $10 \mathrm{~m}$ away from shore.

rBC in the near Shore Zone: Linking Runoff and Middle Lake. The near shore zone (NSZ) of the lake (Figure 1C) is affected by runoff and river inputs and by mixing with the middle lake waters. Figure 6 shows rBC concentrations averaged for distances 1 and $10 \mathrm{~m}$ away from the shore for each site and event. The comparison of Figures 5 and 6 reveals concentrations one to 3 orders of magnitude lower in the NSZ than in South Lake Tahoe runoff, with levels varying from $60 \mu \mathrm{g} / \mathrm{L}$ (March fourth 2007 ) to less than $5 \mu \mathrm{g} / \mathrm{L}$ (April 22nd 2007). Furthermore, we observed a lack of relationship between $\mathrm{rBC}$ concentrations in runoff and in NSZ waters at the four sites investigated, indicating that transfer processes from shore to lake are not straightforward. The NSZ concentrations were inversely related to the discharge rate of the Upper Truckee River with lower concentrations associated with higher discharge rates from snowmelt $\left(\sim 3 \mathrm{~m}^{3} / \mathrm{s}\right.$ in April up to $15 \mathrm{~m}^{3} / \mathrm{s}$ in May $2007^{39}$ ). This likely reflects dilution in the NSZ, which also displayed a sharp gradient (one to 2 orders of magnitude) in $\mathrm{rBC}$ concentrations 10 to $100 \mathrm{~m}$ away from the shore and lower $\mathrm{rBC}$ concentration in water from streams and from the Upper Truckee River. 
Overall, the analysis of stormwater runoff, stream, and near shore waters suggest that concentrations of $\mathrm{rBC}$ in the NSZ are mainly driven by pollution from vehicle emissions around the Lake and by direct urban runoff, probably overcoming natural $\mathrm{rBC}$ levels. The high concentrations (up to $600 \mu \mathrm{g} / \mathrm{L}$ ) found in stormwater runoff have implications for water pollution in large cities where enormous amounts of $\mathrm{rBC}$ must be transferred from roadways and other surfaces by precipitation into urban water systems.

In the midlake, large perturbations in $\mathrm{rBC}$ concentrations appear to be connected with episodic events such as fires and snowmelt. However, considering that $\mathrm{rBC}$ nanoparticles should have very low water deposition rates $(\sim 1 \mathrm{~m}$ /year $)$ it is surprising that concentrations in the lake remain relatively stable and do not build up. The rapid decrease in midlake concentrations following the pulse associated with the fire (Figure 3) is also unexpected knowing such low rates. In the NSZ, we hypothesize that $\mathrm{rBC}$ must be removed through interactions with larger particles and other colloidal species by a combination of adsorption and aggregation, ${ }^{41-43}$ reducing the amount of $\mathrm{rBC}$ transferred to the midlake and driving the sharp gradient in $\mathrm{rBC}$ observed from 1 to $100 \mathrm{~m}$ from shore. Thus, an investigation of $\mathrm{rBC}$ concentrations in the top layer of NSZ sediments could reveal relatively high $\mathrm{rBC}$ content.

However, since Lake Tahoe is oligotrophic and with very low particulate concentrations, ${ }^{44}$ the adsorption of $\mathrm{rBC}$ on other colloids and its removal by aggregation in the middle of the lake is unlikely to account for the changes in concentration. We suggest that additional processes are also needed to explain those rapid changes. These processes may include alteration of $\mathrm{rBC}$ by UV irradiation, ${ }^{45,46}$ uptake and agglomeration by biota, ${ }^{47,48}$ disaggregation and eventual mineralization. ${ }^{27}$ This implies that $\mathrm{rBC}$ is not transported over large distances as an hydrosol and that its transfer from continental pools to oceans likely occurs in association with sediments. Further studies of $\mathrm{rBC}$ and other colloids in lakes and rivers are needed to determine the ultimate mobility and fate of these ubiquitous particles through terrestrial water systems.

\section{ASSOCIATED CONTENT}

S Supporting Information. More details on the calibration of the FIA-SP2 method used in this study and on the determination of $\mathrm{rBC}$ concentrations and in Figure S1 page S2. This material is available free of charge via the Internet at http://pubs. acs.org.

\section{AUTHOR INFORMATION}

\section{Corresponding Author}

*Phone: (775)673-7340; fax: (775)673-7363; e-mail: marion. bisiaux@dri.edu; address: Desert Research Institute, 2215 Raggio Parkway, Reno, NV, 89512, USA.

\section{ACKNOWLEDGMENT}

We thank the anonymous reviewers as well as Martin Gysel (PSI, Switzerland) and Joshua Schwarz (NOAA, Boulder) whose their insightful comments have contributed to the significant improvement of the manuscript. We express our gratitude for the National Science Foundation, the Desert Research Institute, and U.C. Davis for financial support and for support in sample collection and data analysis. Midlake samples were collected as part of the Lake Tahoe Interagency Monitoring Program (LTIMP), supported by funding to UCD from the Tahoe Regional Planning Agency and the Lahontan Regional Water Quality Control Board. Angora Creek samples were collected as part of the Angora Wildfire Water Quality Monitoring Project, supported by grants to DRI and UCD by the California State Water Board, the US Forest Service Lake Tahoe Basin Management Unit, and the Lahontan Regional Water Quality Control Board. We also thank Todd Mihevc of DRI, and Raph Townsend, Brant Allen, and Anne Liston from UC Davis for their assistance in sample collection and processing

\section{REFERENCES}

(1) Masiello, C. A.; Druffel, E. R. M. Black carbon in deep-sea sediments. Science 1998, 280 (5371), 1911-1913.

(2) Simpson, M. J.; Hatcher, P. G. Determination of black carbon in natural organic matter by chemical oxidation and solid-state $13 \mathrm{C}$ nuclear magnetic resonance spectroscopy. Org. Geochem. 2004, 35 (8), 923-935.

(3) Shrestha, G.; Traina, S. J.; Swanston, C. W. Black carbon's properties and role in the environment: A comprehensive review. Sustainability 2010, 2 (1), 294-320.

(4) Masiello, C. A. New directions in black carbon organic geochemistry. Mar. Chem. 2004, 92 (1-4), 201-213.

(5) Ramanathan, V.; Crutzen, P. J.; Kiehl, J. T.; Rosenfeld, D. Atmosphere - aerosols, climate, and the hydrological cycle. Science 2001, 294 (5549), 2119-2124.

(6) Jacobson, M. Z. Strong radiative heating due to the mixing state of black carbon in atmospheric aerosols. Nature 2001, 409 (6821), 695-697.

(7) Ramanathan, V.; Carmichael, G. Global and regional climate changes due to black carbon. Nat. Geosci. 2008, 1 (4), 221-227.

(8) Forbes, M. S.; Raison, R. J.; Skjemstad, J. O. Formation, transformation and transport of black carbon (charcoal) in terrestrial and aquatic ecosystems. Sci. Total Environ. 2006, 370 (1), 190-206.

(9) Kuhlbusch, T. A. J. Black carbon and the carbon cycle. Science 1998, 280 (5371), 1903-1904.

(10) Mitra, S.; Bianchi, T. S.; McKee, B. A.; Sutula, M. Black carbon from the Mississippi river: Quantities, sources, and potential implications for the global carbon cycle. Environ. Sci. Technol. 2002, 36 (11), 2296-2302.

(11) Schneider, J.; Kirchner, U.; Borrmann, S.; Vogt, R.; Scheer, V. in situ measurements of particle number concentration, chemically resolved size distributions and black carbon content of traffic-related emissions on German motorways, rural roads and in city traffic. Atmos. Environ. 2008, 42 (18), 4257-4268.

(12) Suglia, S. F.; Gryparis, A.; Wright, R. O.; Schwartz, J.; Wright, R. J. Association of black carbon with cognition among children in a prospective birth cohort study. Am. J. Epidemiol. 2008, 167 (3), 280-286.

(13) Dickens, A. F.; Gelinas, Y.; Masiello, C. A.; Wakeham, S.; Hedges, J. I. Reburial of fossil organic carbon in marine sediments. Nature 2004, 427 (6972), 336-339.

(14) Lehmann, J.; Skjemstad, J.; Sohi, S.; Carter, J.; Barson, M.; Falloon, P.; Coleman, K.; Woodbury, P.; Krull, E. Australian climatecarbon cycle feedback reduced by soil black carbon. Nat. Geosci. 2008, 1 (12), 832-835.

(15) Lohmann, R.; Bollinger, K.; Cantwell, M.; Feichter, J.; FischerBruns, I.; Zabel, M. Fluxes of soot black carbon to south Atlantic sediments. Global Biogeochem. Cycles 2009, 23, 13.

(16) Dittmar, T. The molecular level determination of black carbon in marine dissolved organic matter. Org. Geochem. 2008, 39 (4), 396-407.

(17) Hockaday, W. C.; Grannas, A. M.; Kim, S.; Hatcher, P. G. The transformation and mobility of charcoal in a fire-impacted watershed. Geochim. Cosmochim. Acta 2007, 71 (14), 3432-3445. 
(18) Kim, S. W.; Kaplan, L. A.; Benner, R.; Hatcher, P. G. Hydrogendeficient molecules in natural riverine water samples - evidence for the existence of black carbon in DOM. Mar. Chem. 2004, 92 (1-4), $225-234$.

(19) Moosmüller, H.; Chakrabarty, R. K.; Arnott, W. P. Aerosol light absorption and its measurement: A review. J. Quant. Spectrosc. Radiat. Transfer 2009, 110 (11), 844-878.

(20) Zhang, R. Y.; Khalizov, A. F.; Pagels, J.; Zhang, D.; Xue, H. X.; McMurry, P. H. Variability in morphology, hygroscopicity, and optical properties of soot aerosols during atmospheric processing. Proc. Natl. Acad. Sci. U.S.A. 2008, 105 (30), 10291-10296.

(21) Posfai, M. 1.; Buseck, P. R. Nature and climate effects of individual tropospheric aerosol particles. Annu. Rev. Earth Planet. Sci. 2010, 38 (1), 17-43.

(22) McConnell, J. R.; Edwards, R.; Kok, G. L.; Flanner, M. G.; Zender, C. S.; Saltzman, E. S.; Banta, J. R.; Pasteris, D. R.; Carter, M. M.; Kahl, J. D. W. 20th-century industrial black carbon emissions altered arctic climate forcing. Science 2007, 317 (5843), 1381-1384.

(23) Gustafsson, O.; Haghseta, F.; Chan, C.; MacFarlane, J.; Gschwend, P. M. Quantification of the dilute sedimentary soot phase: Implications for PAH speciation and bioavailability. Environ. Sci. Technol. 1997, 31 (1), 203-209.

(24) Burkhard, L. P.; Cook, P. M.; Lukasewycz, M. T. Organic carbon-water concentration quotients $\left(\pi_{\mathrm{soc}} S\right.$ and $\left.\pi_{\mathrm{poc}} S\right)$ : Measuring apparent chemical disequilibria and exploring the impact of black carbon in Lake Michigan. Environ. Sci. Technol. 2008, 42 (10), 3615-3621.

(25) Buckley, D. R.; Rockne, K. J.; Li, A.; Mills, W. J. Soot deposition in the Great Lakes: Implications for semi-volatile hydrophobic organic pollutant deposition. Environ. Sci. Technol. 2004, 38 (6), 1732-1739.

(26) Moermond, C. T. A.; Zwolsman, J. J. G.; Koelmans, A. A. Black carbon and ecological factors affect in situ biota to sediment accumulation factors for hydrophobic organic compounds in flood plain lakes. Environ. Sci. Technol. 2005, 39 (9), 3101-3109.

(27) Nguyen, B. T.; Lehmann, J.; Hockaday, W. C.; Joseph, S.; Masiello, C. A. Temperature sensitivity of black carbon decomposition and oxidation. Environ. Sci. Technol. 44, (9), 3324-3331.

(28) Coats, R.; Larsen, M.; Heyvaert, A.; Thomas, J.; Luck, M.; Reuter, J. Nutrient and sediment production, watershed characteristics, and land use in the Tahoe basin, California-Nevada. J. Am. Water Resour. Assoc. 2008, 44 (3), 754-770.

(29) Stephens, M.; Turner, N.; Sandberg, J. Particle identification by laser-induced incandescence in a solid-state laser cavity. Appl. Opt. 2003, 42 (19), 3726-3736.

(30) Moteki, N.; Kondo, Y. Dependence of laser-induced incandescence on physical properties of black carbon aerosols: Measurements and theoretical interpretation. Aerosol Sci. Technol. 2010, 44 (8), 663-675.

(31) Schwarz, J. P.; Spackman, J. R.; Gao, R. S.; Perring, A. E.; Cross, E.; Onasch, T. B.; Ahern, A.; Wrobel, W.; Davidovits, P.; Olfert, J.; et al. The detection efficiency of the single particle soot photometer. Aerosol Sci. Technol. 2010, 44 (8), 612-628.

(32) Slowik, J. G.; Cross, E. S.; Han, J. H.; Davidovits, P.; Onasch, T. B.; Jayne, J. T.; WilliamS, L. R.; Canagaratna, M. R.; Worsnop, D. R.; Chakrabarty, R. K.; et al. An inter-comparison of instruments measuring black carbon content of soot particles. Aerosol Sci. Technol. 2007, 41 (3), 295-314.

(33) Schwarz, J. P.; Gao, R. S.; Fahey, D. W.; Thomson, D. S.; Watts, L. A.; Wilson, J. C.; Reeves, J. M.; Darbeheshti, M.; Baumgardner, D. G.; Kok, G. L.; et al. Single-particle measurements of midlatitude black carbon and light-scattering aerosols from the boundary layer to the lower stratosphere. J. Geophys. Res., [Atmos.] 2006, 111 (D16), 15.

(34) Moteki, N.; Kondo, Y. Effects of mixing state on black carbon measurements by laser-induced incandescence. Aerosol Sci. Technol. 2007, 41 (4), 398-417.

(35) Cross, E. S.; Onasch, T. B.; Ahern, A.; Wrobel, W.; Slowik, J. G.; Olfert, J.; Lack, D. A.; Massoli, P.; Cappa, C. D.; Schwarz, J. P.; et al. Soot particle studies--instrument inter-comparison--project overview. Aerosol Sci. Technol. 2010, 44 (8), 592-611.
(36) Dickens, A. F.; Gélinas, Y.; Hedges, J. I. Physical separation of combustion and rock sources of graphitic black carbon in sediments. Mar. Chem. 2004, 92 (1-4), 215-223.

(37) Mannino, A.; Harvey, H. R. Black carbon in estuarine and coastal ocean dissolved organic matter. Limnol. Oceanogr. 2004, 49 (3), 735-740.

(38) Flores-Cervantes, D. X.; Plata, D. L.; MacFarlane, J. K.; Reddy, C. M.; Gschwend, P. M. Black carbon in marine particulate organic carbon: Inputs and cycling of highly recalcitrant organic carbon in the Gulf of Maine. Mar. Chem. 2009, 113 (3-4), 172-181.

(39) U.S. Geological survey NWIS website. http://waterdata.usgs. gov/nwis (accessed September 15, 2010).

(40) Jansen, K. L.; Larson, T. V.; Koenig, J. Q.; Mar, T. F.; Fields, C.; Stewart, J.; Lippmann, M. Associations between health effects and particulate matter and black carbon in subjects with respiratory disease. Environ. Health Perspect. 2005, 113 (12), 1741-1746.

(41) Koelmans, A. A.; Nowack, B.; Wiesner, M. R. Comparison of manufactured and black carbon nanoparticle concentrations in aquatic sediments. Environ. Pollut. 2009, 157 (4), 1110-1116.

(42) Christian, P.; Von der Kammer, F.; Baalousha, M.; Hofmann, T. Nanoparticles: Structure, properties, preparation and behaviour in environmental media. Ecotoxicology 2008, 17 (5), 326-343.

(43) Vesaratchanon, J. S.; Nikolov, A.; Wasan, D. T. Sedimentation of concentrated monodisperse colloidal suspensions: Role of collective particle interaction forces. J. Colloid Interface Sci. 2008, 322 (1), $180-189$.

(44) Swift, T.; Perez-Losada, J.; Schladow, S.; Reuter, J.; Jassby, A.; Goldman, C. Water clarity modeling in Lake Tahoe: Linking suspended matter characteristics to secchi depth. Aquat. Sci. - Res. Across Boundaries 2006, 68 (1), 1-15.

(45) Lee, J.; Cho, M.; Fortner, J. D.; Hughes, J. B.; Kim, J.-H. Transformation of aggregated c60 in the aqueous phase by UV irradiation. Environ. Sci. Technol. 2009, 43 (13), 4878-4883.

(46) Hwang, Y. S.; Li, Q. Characterizing photochemical transformation of aqueous nC60 under environmentally relevant conditions. Environ. Sci. Technol. 2010, 44 (8), 3008-3013.

(47) Tervonen, K.; Waissi, G.; Petersen, E. J.; Akkanen, J.; Kukkonen, J. V. Analysis of fullerene-C60 and kinetic measurements for its accumulation and depuration in daphnia magna. In John Wiley \& Sons, Inc.: Vol. 29, pp 1072-1078.

(48) Baun, A.; Sørensen, S. N.; Rasmussen, R. F.; Hartmann, N. B.; Koch, C. B. Toxicity and bioaccumulation of xenobiotic organic compounds in the presence of aqueous suspensions of aggregates of nano-C60. Aquat. Toxicol. 2008, 86 (3), 379-387. 